\title{
Surgery for craniovertebral junction pathologies: minimally invasive anterior submandibular retropharyngeal key-hole approach
}

\author{
Árpád Viola ${ }^{1,2^{*}}$, István Kozma ${ }^{3}$ and Dávid Süvegh ${ }^{1}$
}

\begin{abstract}
Background: Our objective was to develop a new, minimally invasive surgical technique for the resolution of craniovertebral junction pathologies, which can eliminate the complications of the previous methods, like liquor-leakage, velopharyngeal insufficiency and wound-dehiscence associated with the transoral or lateral approaches.

Methods: During the first stage of the operation, three patients underwent occipito-cervical dorsal fusion, while the fourth patient received C1-C2 fusion according to Harms. C1-C2 decompressive laminectomy was performed in all four cases. Ventral C1-C2 decompression with microscope assisted minimally invasive anterior submandibular retropharyngeal key-hole approach (MIS ASR) method was performed in the second stage. The MIS ASR-similarly to the traditional anterior retropharyngeal surgery - preserves the hard and soft palates, yet can be performed through a $25 \mathrm{~mm}$ wide incision with the use of only one retractor.
\end{abstract}

Results: The MIS ASR approach was a success in all four cases, there were no intra- and postoperative complications. This method, compared to the transoral approach, provided on average $23 \%\left(4.56 \mathrm{~cm}^{2} / 6.05 \mathrm{~cm}^{2}\right)$ smaller dural decompression area; nonetheless, the entire pathology could be removed in all cases. After the surgery, all patients have shown significant neurological improvement.

Conclusion: Based on the outcome of these four cases we think that the MIS ASR approach is a safe alternative to the traditional methods while improving patient safety by reducing the risk of complications.

Keywords: Odontoidectomy, Minimally invasive, Key-hole approach, Submandibular retropharyngeal, Ventral decompression, Patient safety

\section{Background}

Odontoidectomy serves as the resolution of ventral compression of the upper cervical medulla. It can be performed via traditional transoral, endoscopic endonasal, anterior transcervical retropharyngeal, or with a lateral

\footnotetext{
*Correspondence: arpadviola@gmail.com

${ }^{1}$ Department of Neurotraumatology, Semmelweis University, Fiumei út 17, 1081 Budapest, Hungary

Full list of author information is available at the end of the article
}

approach. The most common method for ventral decompression is by transoral transpharyngeal (TO) odontoidectomy [1] with the option to add a transmandibular route or Le Fort osteotomy for increased visualization and surgical bed [2]. The benefit of endoscopic endonasal (EE) odontoidectomy over the transoral method is that the preservation of the hard and soft palates drastically decreases the risk of velopharyngeal insufficiency, while a straight approach to the odontoid process is still provided [3-5]. The risks and limitations of transmucosal 
surgeries can be avoided with an anterior-transcervicalretropharyngeal approach. Using the standard SmithRobinson method, access to the C3 vertebra and disc is not always attainable, while the anterior retropharyngeal (AR) approach provides access to the whole cervical spine $[6,7]$. Although lateral routes provide wider access, the risk of injuries to the vertebral artery, jugular bulb and hypoglossal nerve are higher [8-11]. Our objective is to introduce a surgical method that we have used for C1$\mathrm{C} 2$ ventral decompression, the microscope assisted minimally invasive anterior submandibular retropharyngeal key-hole approach (MIS ASR), which-similarly to the traditional anterior retropharyngeal surgery-preserves the hard and soft palates, yet can be performed through a $25 \mathrm{~mm}$ wide incision with the use of only one retractor.

\section{Methods}

The development of the MIS ASR procedure was inspired by a trauma case. A cortical bone fragment broke off from the odontoid process of the $\mathrm{C} 2$ vertebra and compressed the spinal cord on the left side [12]. We chose the MIS ASR, because the MRI confirmed a ventral dura injury, which along with the high risk of velopharyngeal insufficiency occurring with the transoral approach, would have increased the risk of wound dehiscence and sepsis. With the submandibular "keyhole" approach, besides using fibrin glue, we could also tamponade the dural injury with multiple layers of vital soft tissue. During the surgery and in the postoperative period, no cerebrospinal fluid (CSF) leakage or other complications presented. After this successful operation on the trauma patient, we began to utilize the MIS ASR key-hole method to assess its feasibility in rheumatoid arthritis and tumorous cases, the two most common reasons for ventral compression. The surgery was performed on two patient in his $60 \mathrm{~s}$ and $80 \mathrm{~s}$ patients with ventral spinal stenosis caused by rheumatoid arthritis, on a patient in her $40 \mathrm{~s}$ to whom the ventral spinal stenosis was due to a metastasis of a cervix squamous-cell carcinoma, and on a patient in his $40 \mathrm{~s}$ with the traumatic odontoid fracture with dislocation resulting in the compression of the medulla oblongata. During the first stage of the operation, three patients underwent occipito-cervical dorsal fusion, while the fourth patient received $\mathrm{C} 1-\mathrm{C} 2$ fusion according to Harms. C1-C2 decompressive laminectomy was performed in all four cases. Ventral C1-C2 decompression was performed in the second stage. All patients were supine, stabilized in Mayfield headrest. During the MIS ASR approach, we began with a $25 \mathrm{~mm}$ wide ventral and submandibular incision, $30-40 \mathrm{~mm}$ below the mental protuberance but cranially from the hyoid bone, beginning from the right side and extending $5 \mathrm{~mm}$ left

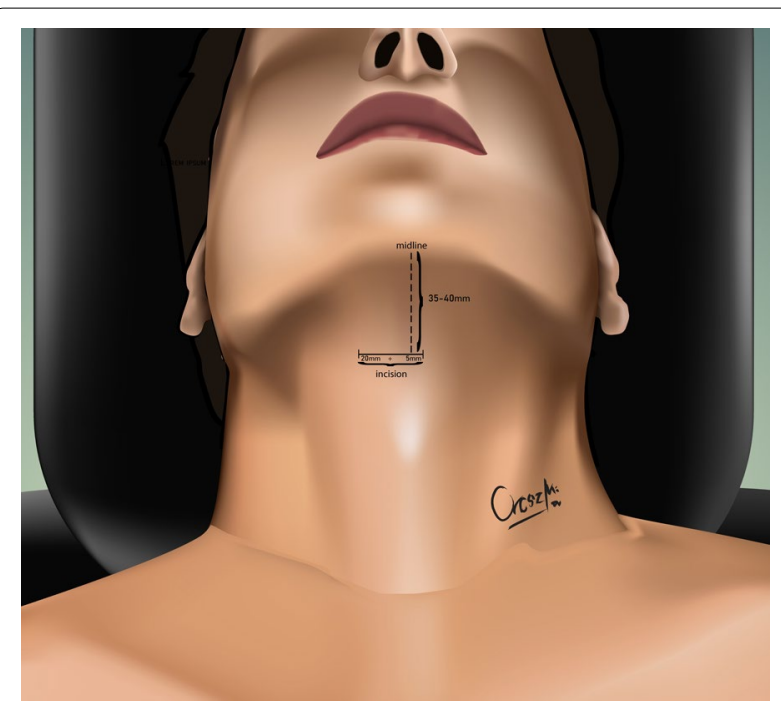

Fig. 1 Location of skin incision

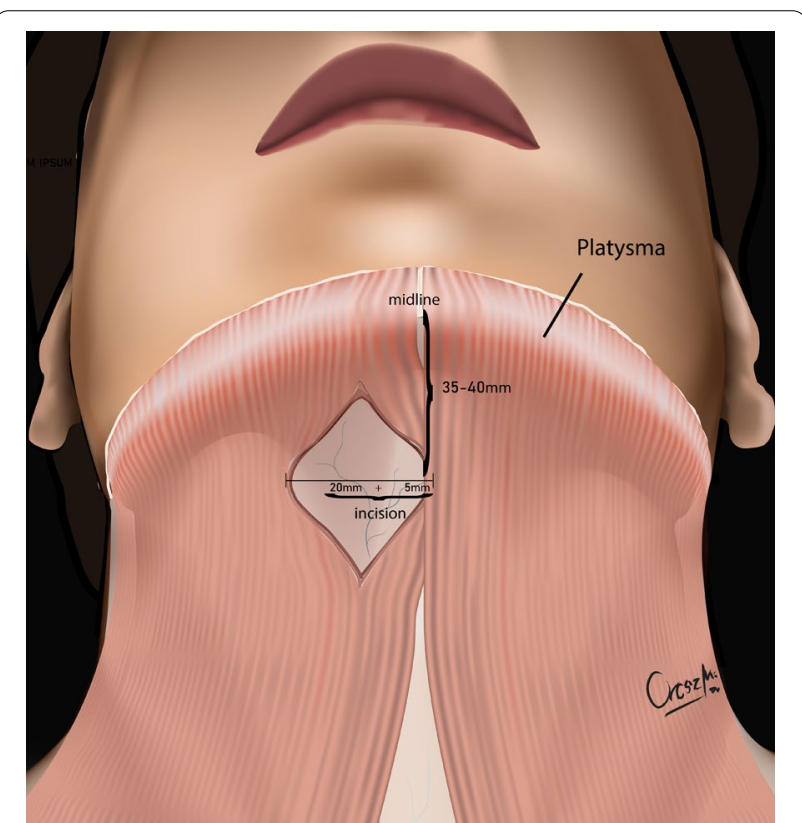

Fig. 2 Vertical dissection of the platysma muscle

towards the midline (Fig. 1). After the skin incision, we visualized the cervical fascia, which we opened with surgical scissors. The platysma muscle was bluntly dissected vertically (Fig. 2), then we retracted laterally the anterior belly of the right digastric muscle. This unfolds the mylohyoid muscle, which we dissected bluntly, horizontally, corresponding to its fibers (Fig. 3). Below that, the geniohyoid muscle was dissected vertically between its fibers. At this point, we inserted a $15 \mathrm{~mm}$ wide-80 $\mathrm{mm}$ long carbon retractor (DePuy Synthes 


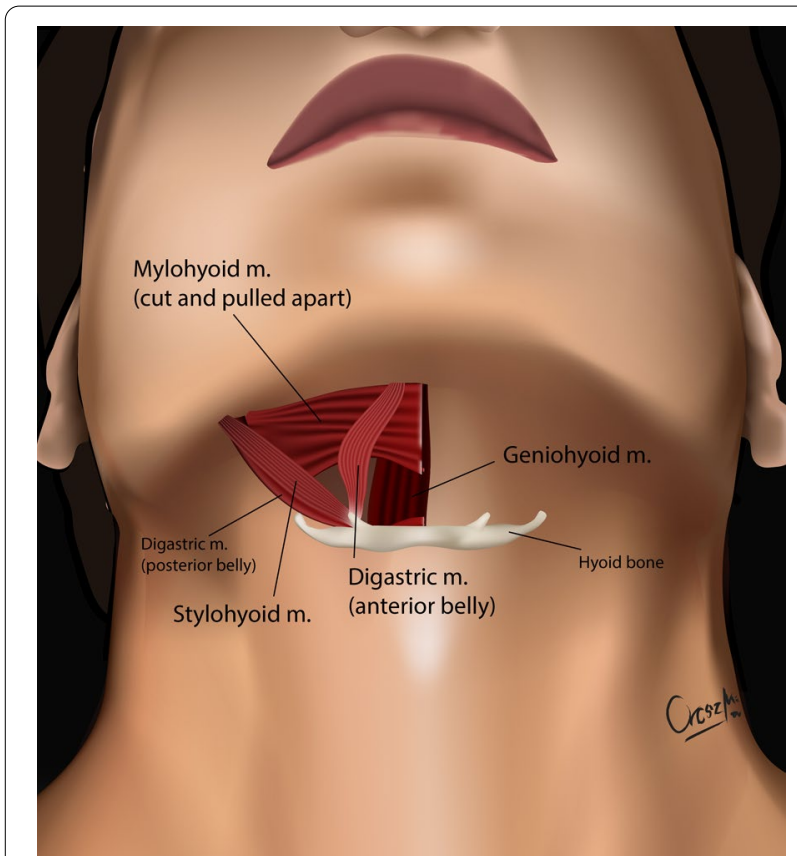

Fig. 3 Retracting and dissecting the deeper muscles of the neck to reach the spinal column

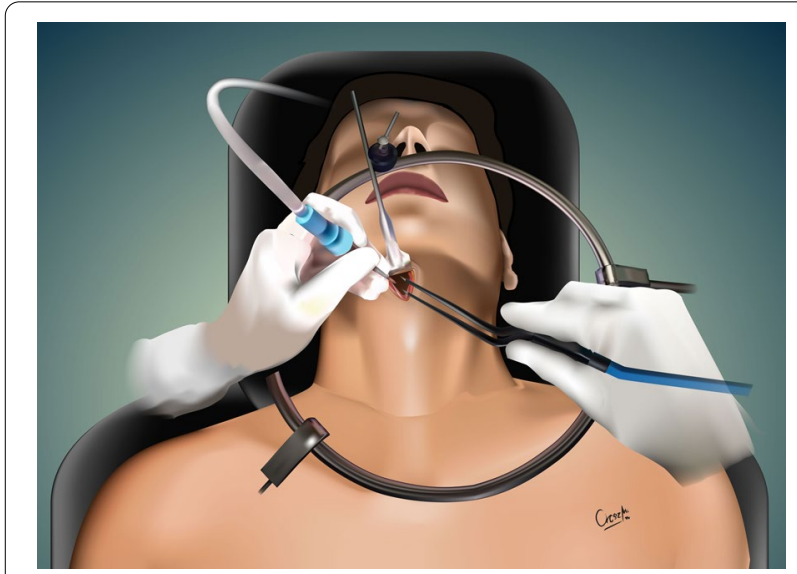

Fig. 4 The carbon retractor attaches to an external holding ring (DePuy Synthes Synframe)

Synframe) reaching the ventral surface of $\mathrm{C} 1$ and $\mathrm{C} 2$ and secured it to the external holding ring (Fig. 4). With this retractor in place, we mobilized the upper portion of the oropharynx cranio-medially to give us access to the upper cervical spine. We could then mobilize the insertion of the longus colli muscle from the anterior tubercle of the atlas (Fig. 5), to freely resect the $\mathrm{C} 1$ vertebra's anterior arch, the odontoid process and the upper portion of the $\mathrm{C} 2$ vertebra. According to the different stages of the surgery, the suction, bipolar

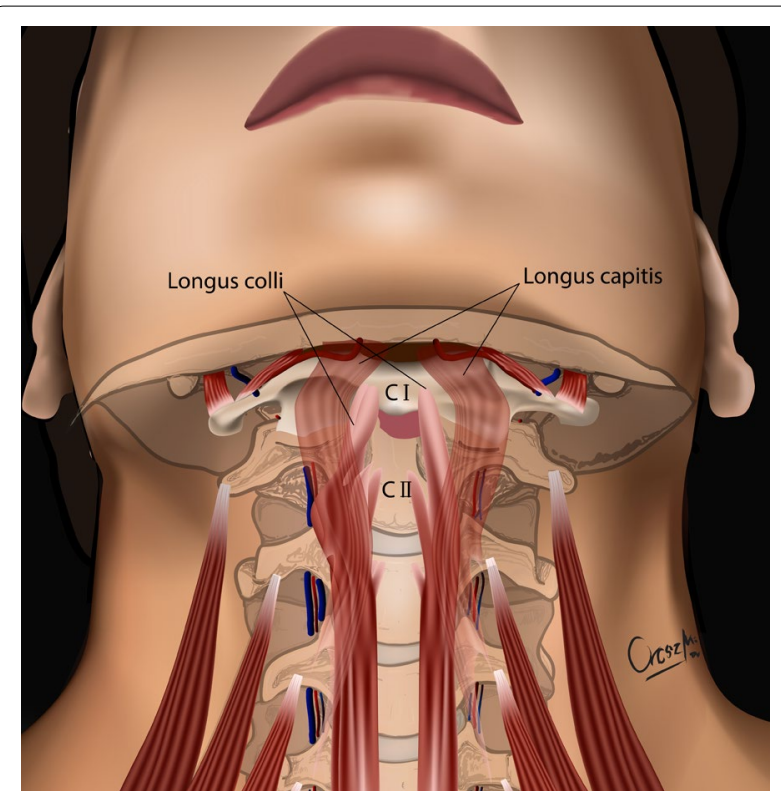

Fig. 5 Insertion of longus colli muscle

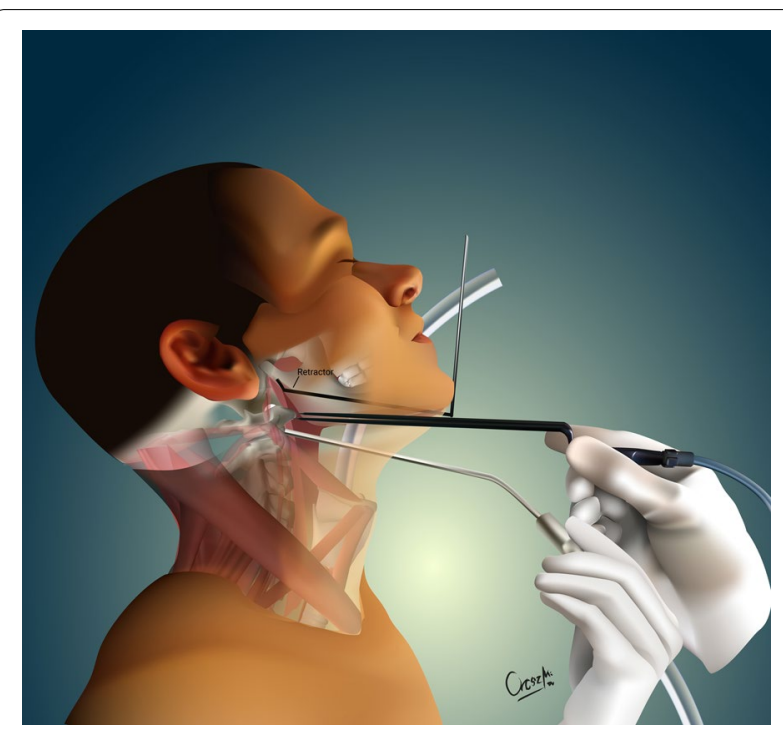

Fig. 6 Mobilization of oropharynx with retractor and retraction of soft tissue with bipolar diathermy and suction

diathermy, micro drill and Kerrison Rongeur were positioned in the surgeon's left and right hand in order to provide adequate retraction of the lateral and medial soft tissue (Fig. 6).

\section{Results}

Using this microscope assisted minimally invasive anterior submandibular retropharyngeal key-hole (MIS ASR) approach, $\mathrm{C} 1-\mathrm{C} 2$ ventral decompression and freeing up 
of the dura mater can be performed. Operative time in the four cases were 165, 150, 135 and 130 min respectively-145 $\mathrm{min}$ on average, and the blood loss was between 80 and $120 \mathrm{ml}$. Tracheostomy was not needed in any of the cases. The patients were extubated immediately after the procedure. They spent $12 \mathrm{~h}$ in the intensive care unit for observation and were started on an oral diet within $24 \mathrm{~h}$. There were no intra- or postoperative complications, and significant neurological improvement presented in every case. An additional movie shows the surgery of the rheumatoid arthritis patient in his $60 \mathrm{~s}$ in detail (Additional file 1). The mean follow-up time was 8.25 months $(15,8,4,6)$. The 83 -year-old male operated due to the rheumatoid pannus died four months after the surgery in Clostridium difficile sepsis. The other three patients are alive, able to walk and are self-sufficient. During the four surgeries-on average-we operated $94.3 \mathrm{~mm}$ deep (108, 95.7, 90.3 and $83 \mathrm{~mm}$ ), measured from the skin incision. This was calculated by averaging the distance measured from the skin surface to the $\mathrm{C} 1$ tubercle, the ventral surface of the $\mathrm{C} 2$ and the deepest point of the freed-up dura in all four cases (altogether 12 values). In each patient, the anterior tubercle of the $\mathrm{C} 1$ vertebra was $105,98,95,78 \mathrm{~mm}$ deep, while the ventral base of the $\mathrm{C} 2$ was $91,79,74,70 \mathrm{~mm}$ respectively. After the removal of bone and soft tissue, the dura mater was $128,110,102,101 \mathrm{~mm}$ deep from the incision (Table 1). The area of decompression was 5.44, 4.84, 4.83 and $3.50-4.65 \mathrm{~cm}^{2}$ in average. This area was measured as a rectangle on the post-operative $\mathrm{CT}$ scans, in the coronal plane, in the level of the ventral surface of the dura. We planned the surgeries with the TO method using CT scans. In these cases, the mean length of the surgical channel would have been $89.8 \mathrm{~mm}$ (86.3, 98.7, 90.3 and $83.7 \mathrm{~mm})-4.5 \mathrm{~mm}$ less than with the MIS ASR. The maximum possible area of decompression, measured in the coronal plane on the CT scans, would have been 7.35, $5.81,5.61$ and $5.44 \mathrm{~cm}^{2}$ to $6.05 \mathrm{~cm}^{2}$ in average.

\section{Patient one}

We admitted male in his $80 \mathrm{~s}$ from a neurological department, with 2-month persistent symptoms and slowly developing paraparesis. The MRI identified a rheumatoid pannus causing ventral compression at the $\mathrm{C} 1-2$ level. Two days after the posterior C1-2 fixation and laminectomy, we performed the MIS ASR surgery without any complications. After the procedure, the patient's paraparesis gradually resolved itself and he became self-sufficient.

\section{Patient two}

The male in his $60 \mathrm{~s}$ presented with moderate tetraparesis, dysphagia, and Bechterew disease in the anamnesis. From the MRI scans we identified a rheumatoid pannus compressing the medulla oblongata. Nine days after the dorsal C1-2 fusion we performed the MIS ASR surgery, during which the anterior arch of $\mathrm{C} 1$, the upper twothirds of the odontoid process, and the pannus causing the compression were removed (Additional file 1). The surgery was completed without complications. The neurological deficit, dysphagia and tetraparesis gradually resolved themselves, and 10 days after the second surgery the patient was discharged to his home.

\section{Patient three}

With the female in her $40 \mathrm{~s}$, the CT and contrast MRI showed the $C 1$ and $C 2$ vertebra's tumorous infiltrationdue to a metastatic cervix squamous cell carcinoma metastasis-which caused the ventral compression of the spinal cord. She had no neurological deficits, only pain in her nape which radiated to the left shoulder. Two days after the occipitocervical-CO-3 dorsal stabilization, we performed the MIS ASR surgery to remove the metastasis and free up the spinal cord. On the fourth day after the second surgery she was discharged to her home with relieved pain.

Table 1 The length of the surgical channel with the MIS ASR and the TO method

\begin{tabular}{|c|c|c|c|c|c|c|c|c|}
\hline \multirow[t]{2}{*}{ No. of patient } & \multicolumn{4}{|l|}{ MIS ASR } & \multicolumn{4}{|l|}{ TO } \\
\hline & $\mathrm{I}-\mathrm{C} 1(\mathrm{~mm})$ & $\mathrm{I}-\mathrm{C} 2(\mathrm{~mm})$ & I-D (mm) & $\mathrm{DF}\left(\mathrm{cm}^{2}\right)$ & $\mathrm{O}-\mathrm{C} 1(\mathrm{~mm})$ & $\mathrm{O}-\mathrm{C} 2(\mathrm{~mm})$ & O-D (mm) & $\mathrm{DF}\left(\mathrm{cm}^{2}\right)$ \\
\hline 1 & 105 & 91 & 128 & 3.50 & 76 & 85 & 98 & 5.81 \\
\hline 2 & 98 & 79 & 110 & 4.83 & 89 & 96 & 111 & 7.35 \\
\hline 3 & 95 & 74 & 102 & 5.44 & 77 & 93 & 101 & 5.44 \\
\hline 4 & 78 & 70 & 101 & 4.84 & 74 & 86 & 91 & 5.61 \\
\hline
\end{tabular}

MIS ASR minimally invasive anterior submandibular retropharyngeal key-hole approach, TO transoral approach, I-C1 distance between the incision and C1 vertebra's anterior tubercle, $I-C 2$ distance between the incision and the ventral base of $C 2$ vertebra, $I-D$ distance between the incision and the deepest point of the dura mater, $D F$ decompressed dura mater surface, $\mathrm{O}-\mathrm{C} 1$ distance between the orifice and $\mathrm{C} 1$ vertebra's anterior tubercle, $\mathrm{O}-\mathrm{C} 2$ distance between the orifice and the ventral base of $C 2$ vertebra, $O-D$ distance between the orifice and the deepest point of the dura mater 


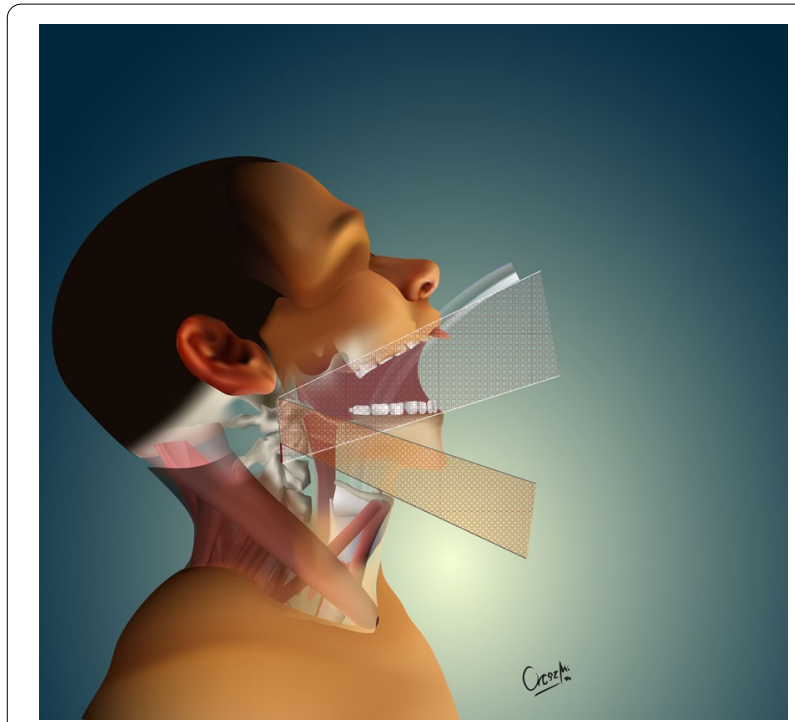

Fig. 7 Schematic figure of different surgical interventions. Legend: white line: maximum decompression area with the transoral method, black line: maximum decompression area with the anterior submandibular retropharyngeal method, red line: the difference between the two methods' decompression area

\section{Patient four}

The male in his $40 \mathrm{~s}$ had a motorcycle accident, and the CT showed that he had suffered an Anderson-D'Alonso type II. Odontoid fracture, during which a $17 \mathrm{~mm}$ long cortical bone fragment from the process broke off and punctured the dura while causing compression to the medulla oblongata. The MRI scan confirmed liquorleakage behind the odontoid process and showed injury to the posterior ligamentous complex. The patient was tetraplegic on admission. At the first step, we performed an emergency $\mathrm{C} 1-2$ fusion and the removal of the posterior arch of the $\mathrm{C} 1$ vertebra to decompress the medulla oblongata. Due to the patient's instable circulatory system we could not perform the ventral decompressive surgery immediately, but only 7 days later. During this MIS ASR procedure, we removed the middle third of the odontoid process, as well as the haematoma and the cortical bone fragment causing the compression. In the course of the operation we also explored the dural injury, and successfully tamponaded and tissue-glued it. The patient is now self-sufficient.

\section{Discussion}

The most common complications associated with transoral and transnasal odontoidectomy are CSF leakage, velopharyngeal insufficiency, wound dehiscence, pulmonary issues, meningitis and death [13]. In a systematic review, after analyzing 26 publications, Shriver et al. found that the only statistically significant difference between the complication rates of the two methods was the increased incidence of tracheostomy after transoral
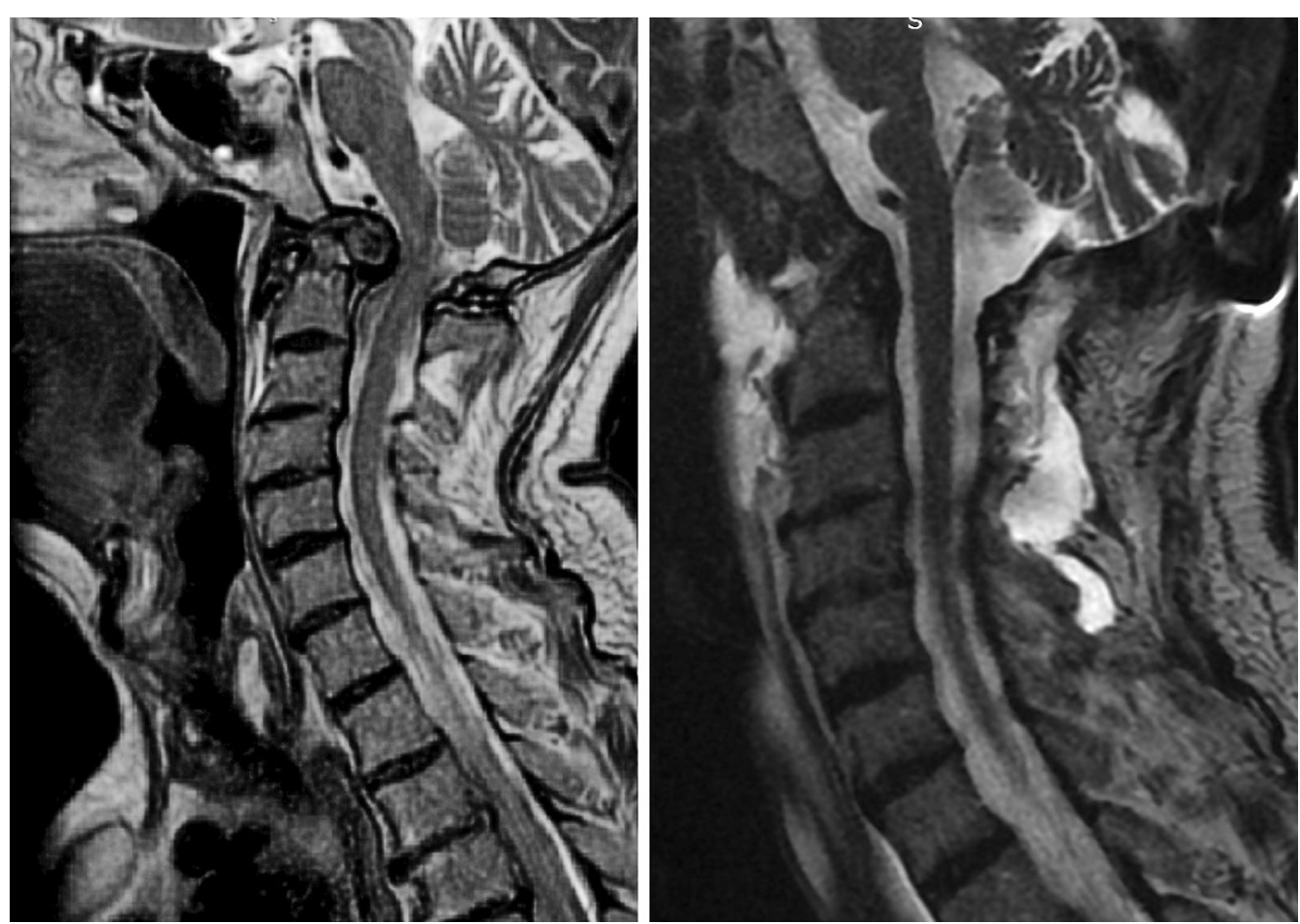

Fig. 8 The preoperative (left) and postoperative (right) magnetic resonance (MRI-T2) imaging of the male patient in his $60 \mathrm{~s}$. All images, figures and additional materials are the authors', no materials are used from another source 
surgeries $[13,14]$. Although the lateral routes provide a wider access, the risk of vertebral artery, jugular bulb and hypoglossal nerve injuries are higher [8-11]. PonceGómez et al. found a significant difference between the time duration of the TO and EE approaches. TO surgeries lasted $141 \mathrm{~min}$ in average, while the EE-s lasted 238 min, $\mathrm{p} \leq 0.02$. Patients, who received the EE procedure, could be extubated immediately after the surgery, while patients who underwent the TO method stayed intubated for $24 \mathrm{~h}$. Time until oral feeding was significantly shorter in the EE group, $\mathrm{p} \leq 0.009$ [15].

The minimally invasive anterior submandibular retropharyngeal key-hole approach we used is a novel method for the decompression of $\mathrm{C} 1, \mathrm{C} 2$ ventral pathologies. From the four presented cases, we cannot come to long term conclusions, but we can state that during the MIS ASR - with the preservation of the hard and soft palates-the risk of velopharyngeal insufficiency associated with the TO method can be eliminated, as well as the risk of liquor-leakage. The blood-loss is minimal, the patients do not need tracheostomy, and can be started on oral diet within $24 \mathrm{~h}$ after surgery. The MIS ASR, compared to the TO method, provided on average $23 \%\left(4.56 \mathrm{~cm}^{2} / 6.05\right.$ $\mathrm{cm}^{2}$ ) smaller dural decompression area. We believe that this $1.40 \mathrm{~cm}^{2}$ difference occurs due to the fact that during the MIS ASR surgery-compared to the TO method-the distance between the $\mathrm{C} 1$ anterior tubercle and the midline of the corpus of $\mathrm{C} 2$ is seen at a more obtuse angle, reducing the possible area of decompression by 1.40 $\mathrm{cm}^{2}$ (Fig. 7). Nonetheless, the entire pathology could be removed and sufficient decompression could be achieved in all cases (Fig. 8). The small-25 $\mathrm{mm}$ wide -incision, the deep surgical field ( $94.3 \mathrm{~mm}$ on average), and the narrow surgical channel require proficient microsurgical skills.

\section{Conclusions}

The novel, microscope assisted minimally invasive anterior submandibular retropharyngeal key-hole approach was feasible for dens resection in these four cases but further studies are required.

\section{Abbreviations}

MIS ASR: Microscope assisted minimally invasive anterior submandibular retropharyngeal; TO: Transoral transpharyngeal odontoidectomy; EE: Endoscopic endonasal odontoidectomy; AR: Anterior retropharyngeal; MRI: Magnetic resonance imaging; CSF: Cerebrospinal fluid; CT: Computed tomography.

\section{Supplementary Information}

The online version contains supplementary material available at https://doi. org/10.1186/s12893-021-01198-z.

Additional file 1.

\section{Acknowledgements}

Not applicable.

\section{Authors' contributions}

ÁV developed and performed the surgical intervention, drafted the manuscript, and supervised the work. IK assisted during the operations, collected and processed the necessary data and patient documentation. DS assisted during the operation, collected and processed the necessary data and patient documentation and contributed to the final form of the manuscript. Each author has approved the submitted version and hold themselves accountable for the author's own contributions and ensure that the accuracy and integrity of any work are appropriately investigated, resolved and documented.

\section{Funding}

The authors included in this study have no applicable financial relationships to disclose. Specifically, there are no study funding sources or potential conflict of interest associated biases to disclose.

\section{Availability of data and materials}

All data generated or analyzed during this study are included in this published article.

\section{Declarations}

\section{Ethics approval and consent to participate}

Ethical approval was waived by the local Ethics Committee of the National Traumatology Institution in view of the retrospective nature of the study and all the procedures being performed were part of the routine care. The Ethics Committee approved the publication of this retrospective paper in the decision with the ID number 02/2021/National Traumatology Institute (Péterfy Sárdor Utcai Kórház - Rendelőintézet és Baleseti Központ Kutatásetikai Bizottsága). In the first - trauma - case, the procedure was performed with emergency, vital indications with the written consent of a relative and the approval of the institute's management. The Ethics Committee (Péterfy Sárdor Utcai Kórház - Rendelőintézet és Baleseti Központ Kutatásetikai Bizottsága) later approved the procedure for further use, therefor no special patient consent was needed. All patients gave informed written consent to the general hospital and surgical care.

\section{Consent for publication}

All participant gave written consent for their clinical data to be published. We do not publish any identifying personal information or images - clinical or otherwise.

\section{Competing interests}

The authors declare that they have no competing interests.

\section{Author details}

${ }^{1}$ Department of Neurotraumatology, Semmelweis University, Fiumei út 17, 1081 Budapest, Hungary. ${ }^{2}$ Department of Neurosurgery and Neurotraumatology, Péterfy Hospital - Manninger Jenő National Traumatology Institution, Fiumei út 17, 1081 Budapest, Hungary. ${ }^{3}$ Péterfy Hospital - Manninger Jenő National Traumatology Institution, Fiumei út 17, 1081 Budapest, Hungary.

Received: 5 October 2020 Accepted: 8 April 2021

Published online: 19 April 2021

\section{References}

1. lacoangeli M, Di Rienzo A, Colasanti R, Re M, Nasi D, Nocchi N, et al. Endoscopic transnasal odontoidectomy with anterior $\mathrm{C} 1$ arch preservation and anterior vertebral column reconstruction in patients with irreducible bulbomedullary compression by complex craniovertebral junction abnormalities: operative nuance. Oper Neurosurg. 2016;12(3):222-30.

2. Ishida W, McCormick KL, Lo SFL. Craniocervical approach: transcervical. In: Sciubba DM, editor. Spinal tumor surgery. Cham: Springer; 2019. p. 29-41.

3. Yu Y, Hu F, Zhang X, Sun C. Endoscopic transnasal odontoidectomy. Sports Med Arthrosc Rev. 2016;24(1):2-6. 
4. Zoli M, Mazzatenta D, Valluzzi A, Mascari C, Pasquini E, Frank G. Endoscopic endonasal odontoidectomy. Neurosurg Clin N Am. 2015:26(3):427-36.

5. lacoangeli M, Gladi M, Alvaro L, Di Rienzo A, Specchia N, Scerrati M. Endoscopic endonasal odontoidectomy with anterior $\mathrm{C} 1$ arch preservation in elderly patients affected by rheumatoid arthritis. Spine J. 2013;13(5):542-8

6. Hodges SD, Humphreys SC, Brown TW Jr, Eck JC, Covington LA. Complications of the anterior retropharyngeal approach in cervical spine surgery: a technique and outcomes review. J South Orthop Assoc. 2000;9(3):169-74.

7. Srivastava SK, Aggarwal RA, Nemade PS, Bhosale SK. Single-stage anterior release and posterior instrumented fusion for irreducible atlantoaxial dislocation with basilar invagination. Spine J. 2016;16(1):1-9.

8. Al-Mefty O, Borba LA, Aoki N, Angtuaco E, Pait TG. The transcondylar approach to extradural nonneoplastic lesions of the craniovertebral junction. J Neurosurg. 1996;84(1):1-6.

9. Stevenson GC, Stoney RJ, Perkins RK, Adams JE. A transcervical transclival approach to the ventral surface of the brain stem for removal of a clivus chordoma. J Neurosurg. 1966;24(2):544-51.

10. Perrini P, Benedetto N, Guidi E, Di Lorenzo N. Transoral approach and its superior extensions to the craniovertebral junction malformations: surgical strategies and results. Neurosurgery. 2009;64(5 Suppl 2):331-42.
11. Ture U, Pamir MN. Extreme lateral-transatlas approach for resection of the dens of the axis. J Neurosurg. 2002;96(1 Suppl):73-82.

12. Suvegh D, Viola A. Microscope-assisted odontoid resection via submandibular retropharyngeal "key-hole" approach. Orv Hetil. 2020;161(31):1302-6.

13. Tubbs RS, Demerdash A, Rizk E, Chapman JR, Oskouian RJ. Complications of transoral and transnasal odontoidectomy: a comprehensive review. Childs Nerv Syst. 2016;32(1):55-9.

14. Shriver MF, Kshettry VR, Sindwani R, Woodard T, Benzel EC, Recinos PF. Transoral and transnasal odontoidectomy complications: a systematic review and meta-analysis. Clin Neurol Neurosurg. 2016;148:121-9.

15. Ponce-Gomez JA, Ortega-Porcayo LA, Soriano-Baron HE, SotomayorGonzalez A, Arriada-Mendicoa N, Gomez-Amador JL, et al. Evolution from microscopic transoral to endoscopic endonasal odontoidectomy. Neurosurg Focus. 2014;37(4):E15.

\section{Publisher's Note}

Springer Nature remains neutral with regard to jurisdictional claims in published maps and institutional affiliations.
Ready to submit your research? Choose BMC and benefit from:

- fast, convenient online submission

- thorough peer review by experienced researchers in your field

- rapid publication on acceptance

- support for research data, including large and complex data types

- gold Open Access which fosters wider collaboration and increased citations

- maximum visibility for your research: over $100 \mathrm{M}$ website views per year

At BMC, research is always in progress.

Learn more biomedcentral.com/submissions 